\title{
GENERAL METHOD OF BACTERIA, THEIR PHAGES AND OTHER PATHOGENS DETECTION IN FUNGI AND PLANTS
}

\author{
A. Boiko', Ya. Chabaniuk ${ }^{2}$, O. Boiko ${ }^{3}$, A. Orlovskyi², \\ O. Melnychuk ${ }^{2}$, V. Tsvihun ${ }^{2}$ \\ ${ }^{1}$ Інститут мікробіології і вірусологї̈ ім. Д.К. Заболотного НАН України \\ ${ }^{2}$ Інститут агроекології і природокористування НААН \\ ${ }^{3}$ Національний університет біоресурсів і природокористування України
}

\begin{abstract}
Проаналізовано рослинні об'єкти та їстівні і лікарські гриби методом електронномікроскопічних досліджень на ураження бактеріями, їх фагами, вірусами, мікроскопічними грибами. Основою методичної розробки є контрастування збудників хвороб безпосередньо у підготовленій коміриі на плодових тілах грибів базидіоміцетів та рослинному матеріалі (клена, груші, буряку столового, опунції). Метод надає можли вість виявити патогени різних таксономічних груп в умовах латентної інфекції та простежити за процесом патології на досліджуваних об'єктах.
\end{abstract}

Ключові слова: бактерії, фаги, фітовіруси, гриби, рослини, електронна мікроскопія, солі важких металів, екологічна ніша.

During the current period of unbalanced environmental conditions highly topical are the processes of selection, diagnosis and prevention of different taxonomic groups of pathogens, which affect the edible and medicinal fungi, plants and other organisms [1]. It should be noted that these technological processes require significant multiple expenses [2]. Furthermore, the selection of disease pathogens based on many biological and physical methods frequently motivates researchers to interpret the size of pathogens, their morphological and structural features in different ways. Such methodical processes cause considerable changes in viruses, bacteria and microscopic fungi structures, which lose their natural activity appropriate to these biological objects [3]. Nowadays, there is a number of traditional and modern methods used for isolation and identification of disease pathogens such as immunologic tests, PCR, electron microscopy of various purpose (transmissive, scanning, atomic-power), electrophoresis of proteins and nucleic acids

(C) A. Boiko, Ya. Chabaniuk, O. Boiko, A. Orlovskyi, O. Melnychuk, V. Tsvihun, 2017
(RNA and DNA), technological processes of selection and investigation of bacterial viruses, usage of nutrient media [4, 5].

All the methods, as it is known, require primary screening of objects affection by pathogens of different nature and such methodical approach should provide an opportunity to determine latent infection, morphological characteristics of pathogens, their place of localization, circulation in the appropriate organic plants, fungi and other organisms. The aim of our research was to adapt express method for possible diagnosis of pathogens in different types of plants and fungi in conditions of mixed infection.

Proposed method of detecting pathogens allows using prolonged processes in experiments in order to study molecular and biological properties of disease pathogens of various biological objects.

\section{RESEARCH MATERIALS AND METHODS}

Forest champignon (agaricus sievaticus), double-spore champignon (agaricus bisporus); oyster fungus (pleurotus ostreatus); different types of prickly pear of the family 
Coctaceae (botanical gardens of Ukraine); commercial varieties of pears (fruit) of varieties «Parizhanka»; branches of different layers of Norway maple (Acer platanoides); root vegetables (uterine landings) of table beet of «Delikatesnyi» varieties were used in the experiments. The latter one was involved into specialized experiments under the following conditions: soaking of its root crops, processing after vegetation and seeds before sowing in $0.1 \%$ concentration of some variants of working breeding by stimulator of plant growth and development of biocomposition «Bioekofunhe 1» (developers of the Department of physiology, biochemistry and bioenergy of NULES). At the same beet roots (mother plantation) were soaked with following exposition of 60 minutes, vegetating plants in regular intervals were treated with a preparation twice (interval between spraying within 10 days), seeds before sowing were soaked for 90 minutes. All variants of experiments were carried out in 3 repetitions. Unprocessed plants, which were cultivated without using a stimulator, served as control. This express method of identifying pathogens was applied based on analyzes of root crops of mother plantation and commercial root crops. The point of technique was the dynamics of technological process based on the contrasting of biological objects in lighted juice, which appeared at the bottom of before prepared unit (4-5 mm). Thus phosphotungstic acid or uranyl acetate were kept in a substrate unit during 1.5-2.5 minutes following by catching grid and composite fluid with one-time movement of tweezers and dried it in a sterile Petri dishes on filter paper. After drying (30-45 minutes) the preparation was investigated in electronic transmissive microscope under conditions of instrumental increasing in 15-45 thousand times (EM-125 microscope; JEM-1400) (Fig.).

We express a sincere gratitude to the sanitary microbiology laboratory staff of the D.K. Zabolotny Institute of Microbiology and Virology of NAS of Ukraine.

\section{RESEARCH RESULTS AND DISCUSSION}

Approbation of express methods and analysis of research results provide an opportunity to note that the proposed and worked out process of identifying pathogens in different types of biological objects is a reliable way to diagnose disease pathogens at the mixed infections that often affects plants and fungi in the ecological niches latently. In addition, the proposed method allows determining the dynamics of their infection development, to get morphological and structural parameters of pathogens that are reviewed in the visual field while maintaining their nativeness that is essential for taxonomic determining of pathogens. It should be noted that bacteria

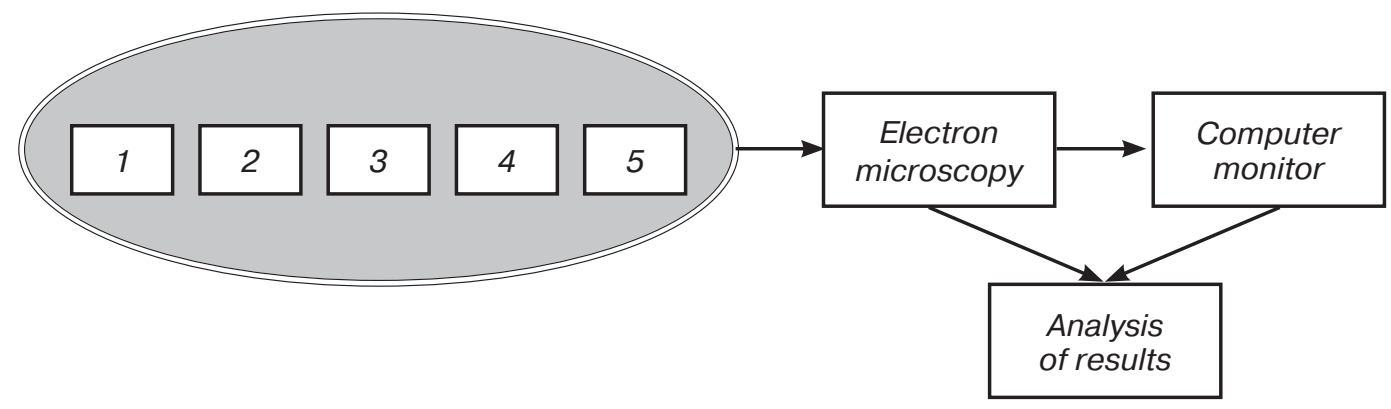

Schematic process of detection and diagnostics of pathogens:

1. Sample of pears

2. Sample of maple

3. Sample of fungi basidiomycetes

4. Sample of table beet

5. Sample of oyster fungi 
and their phages, baculiform and rhabdoviruses, some fragments of microscopic fungi are the most often clearly identified when viewing 10-20 fields of preparation. Thus a pear (fruit) had the highest percentage of Erwinia bacteria (32\%) and their phages, maple was contaminated according to the following observations by penicillamineon for $4.0 \%$ and for $3.0 \%$ by rod-shaped particles (TMV). The results of previous researches about lesions of bisporus champignon by pseudomonads bacteria (25\%) and at the same time phage adsorption was marked on bacterial surface are confirmed. In this type of fungi also rhabdoparticles and viruses (Totiviride), which have cubic type of symmetry, were observed. These pathogens were visualized on the microscope screen of fungi that were grown in a transformed environment. It is noticed that forest fungus (natural ecosystems) was a «carrier» of unidentified structures of various sizes of spherical and oblong shape. In oyster fungus under different conditions of its cultivation, penicillium, fusariose $11 \%$ was detected as well as spherical virus.

It is important that express method allows to control the quality of table beet roots that were grown for different purposes (uterine landings, commercial table beets). In the spe- cialized experiment were different variants: control, soaking of seed roots, processing of vegetating plants by the stimulator of growth and development - «Bioekofunhe- $1 »-0.1 \%$ working solution. After processing in all variants was significantly decreased the presence of the pathogens of various taxonomic groups in roots. In the variant after roots soaking in a preparation the development of pathogens was blocked up by $65-82 \%$. Thus seed plants (landings) develop activity with higher effectiveness level.

It should be noted that proposed method can be applied to the assessment of selection and genetic material of plants and with appropriate modifications for control agar medium in Petri dishes when determining microflora of various diseases in medical and biological scientific institutions.

\section{CONCLUSIONS}

1. The proposed express method allows detecting disease pathogens of various types of organisms under conditions of mixed infection and latent period of the disease.

2. The developed methodology can be used in scientific and production laboratories of AIC and other specialized multi-profile institutions.

\section{ЛIТЕРАТУРА}

1. Атабеков И.Г. Практикум по вирусологии / И.Г. Атабеков. - М.: Изд-во Московського университета, 1981. - $190 \mathrm{c}$.

2. Бойко O.A. Морфологія та структурні особливості патогенів Basidiomycetes / О.А. Бойко, Т.П. Шевченко, А.Л. Бойко // Мікробіологічний журнал. - 2013. - T. 76, № 3 . - C. 50-61.

3. Monitoring of some phytoviral infections in the Ukraine / V. Polischuk, A. Boyko, D. Spaar et al.
/ Arch. Phytopath. Pflanz. - 1998. - Vol. 31. - P. 459-464.

4. Бойко А.Л. Рослини родини Cactaceaе в ботанічних садах України / А.А. Бойко, Т.М. Сахно, О.Г. Коваленко / Мікробіол. журн. - 1972. - Вип. 34.4. С. 523-525.

5. Билай В. Микроорганизмы - возбудители болезней растений / В. Билай; под. ред. чл-кор. АН УССР В.И. Билай. - К.: Наукова думка, 1988. - 550 с.

\section{REFERENCES}

1. Atabek I.G. (1981). Praktykum po vyrusolohyy [Workshop on virology ]. Moscow: Moscow University Publ., 190 p. (in Russia).

2. Boyko O.A. . Shevchenko T.P, Boyko A.L. (2013). Morfolohiya ta strukturni osoblyvosti patoheniv Basidiomycetes [The morphology and structural features of pathogens Basidiomycetes]. Mikrobiolohichnyy zhurnal [Mikrobiologichny Zhurnal], Vol. 76. No. 3, pp. 50-61 (in Ukrainian).

3. Polischuk V., Boyko A., Spaar D., Budzanivska I., Boubriak O., Tyvonchuk T. (1998). Monitoring of some phytoviral infections in the Ukraine. Arch.
Phytopath. Pflanz., Vol. 31, pp. 459-464 (in English).

4. Boyko A.L. Sakhno T.N, Kovalenko O.H. (1972). Roslyny rodyny Cactaceae v botanichnykh sadakh Ukrayiny [Family Cactaceae plants in botanical gardens Ukraine]. Mikrobiolohichnyy zhurnal [Mikrobiologichny Zhurnal], Vol. 34.4, pp. 523-525 (in Ukrainian)

5. Bill W. (1988). Mykroorhanyzmy - vozbudytelybolezney rasteny [Mykroorhanyzm - vozbudytelybolezney plants]. Kyiv: Naukova dumka Publ., 550 p. (in Ukrainian). 